\title{
Pharmacokinetics and pharmacodynamics of monoclonal antibodies for asthma treatment
}

\section{Diego Bagnasco, Enrico Heffler, Elisa Testino, Giovanni Passalacqua \& Giorgio Walter Canonica}

To cite this article: Diego Bagnasco, Enrico Heffler, Elisa Testino, Giovanni Passalacqua \& Giorgio Walter Canonica (2019): Pharmacokinetics and pharmacodynamics of monoclonal antibodies for asthma treatment, Expert Opinion on Drug Metabolism \& Toxicology, DOI: 10.1080/17425255.2019.1568409

To link to this article: https://doi.org/10.1080/17425255.2019.1568409

Accepted author version posted online: 11 Jan 2019.

Submit your article to this journal $\llbracket$

View Crossmark data $\nearrow$ 
Publisher: Taylor \& Francis

Journal: Expert Opinion on Drug Metabolism \& Toxicology

DOI: $10.1080 / 17425255.2019 .1568409$

\title{
Pharmacokinetics and pharmacodynamics of monoclonal antibodies for asthma treatment
}

\author{
Diego Bagnasco ${ }^{1}$, Enrico Heffler ${ }^{2}$, Elisa Testino ${ }^{1}$, \\ Giovanni Passalacqua ${ }^{1}$, Giorgio Walter Canonica ${ }^{2, *}$
}

1 Allergy \& Respiratory Diseases, DIMI Department of Internal Medicine,

University of Genoa, IRCCS AOU San Martino-IST, Genoa, Italy

2 Department of Internal Medicine, Respiratory Disease Clinic, IRCCS

Humanitas Clinical and Research Center, Humanitas University, Rozzano-Milan, Italy

\begin{abstract}
*Corresponding Author:
Giorgio Walter Canonica

Department of Internal Medicine, Respiratory Disease Clinic,

Humanitas Clinical and Research Center, Humanitas University, Rozzano-Milan, Italy

Mail: giorgio walter.canonica@hunimed.eu
\end{abstract}

\section{ABSTRACT}

Introduction: Asthma is a chronic inflammatory airway disease. It occurs in a "severe" form in about $8-10 \%$ of asthmatic patients. In the last decade the development of biological drugs (e.g. monoclonal antibodies) allowed to efficiently approach severe asthma. The current therapeutic targets available are mainly those related to TH2 inflammation.

Areas covered: The main pharmacokinetic and pharmacodynamic characteristics of the monoclonal antibodies against IL-5, IL-5Ra, IL4-IL13 and IgE, that are currently marketed or understood for severe asthma are discussed in this paper.

Expert opinion: The currently available biological drugs represent an excellent therapeutic add-on to traditional drugs, especially in replacing systemic corticosteroid therapies. The different pharmacokinetic and pharmacodynamic characteristics of the drugs, despite sometime sharing the 
same target, would allow a better personalization of the therapy, tailoring the treatment to the characteristics of the patient.

Key Words: severe asthma, pharmacokinetic, pharmacodynamics, monoclonal antibodies, biological drugs, precision medicine, personalized medicine

\section{ABBREVIATIONS:}

ADCC: antibody-dependent cell-mediated cytotoxicity

$\mathrm{AUC}_{\infty}$ : area under the serum concentration-time curve

ICS: inhaled corticosteroids

Cmax: Maximum plasma concentrations

IV: intravenous

LABA : long-acting beta2-agonists

mAB : monoclonal antibody

PD: pharmacodynamic

PK: pharmacokinetic

SC: subcutaneous

TH: T Helper lymphocyte 
Article highlights:

1. Monoclonal antibodies are an efficient therapy in patients with severe asthma

2. Biological drugs currently marketable can be used in patients with an allergic or an eosinophilic phenotype of asthma

3. The pharmacokinetic and pharmacodynamic aspect of these drugs makes them different from each other despite, in some cases, the biological target is the same

4. The point of inoculum of these drugs modifies the pharmacokinetics mechanisms, therefore it is necessary to use the one suggested by clinical trials to guarantee a correct absorption

5. Although these drugs have different routes of administration, they have proved equally effective, despite this modifying PK and PD

\section{INTRODUCTION}

Asthma is a chronic airways disease, with high incidence and prevalence, usually sustained by a bronchial inflammatory process. It is estimated that about 235 million of people suffer from asthma, and the prevalence of this disease is still rising worldwide [1,2]. About $10 \%$ of asthmatic subjects have a severe uncontrolled form of the disease [3]. These patients, according to ATS/ERS guidelines, though receiving the highest dose of inhaled therapies, principally based on inhaled corticosteroids (ICS) and long-acting beta2-agonists (LABA), are not controlled and must take other drugs to try to control the disease [4]. People with uncontrolled severe asthma have a higher risk of exacerbations, morbidity and mortality, not to mention the direct and indirect economic burden on the healthcare system [5]. In recent years some biological drugs have been developed to provide a therapeutic response to a part of patients who do not respond adequately to traditional therapies. Nowadays these drugs are mainly targeted to those patients with prevalent T Helper (TH)2-type inflammation [6,7], that is, for historical and cultural reasons, the better known.

2. THERAPEUTIC TARGETS OF mABs

Currently many biological agents with different biological targets are under clinical experimentation, but only drugs directed on $\operatorname{IgE}$ and eosinophils have been marketed. Both mechanisms represent different faces of the same type of asthma, namely the TH2-dominant phenotype. Frequently, type 2-immunity is activated by the exposure to allergens and it develops by 
the differentiation of naïve T CD4+ cells, associated with IgE production, increase in peripheral eosinophils and allergen-triggered mast cell activation. The principal cytokines involved in type 2 immune response are interleukin (IL) 4, IL-5, IL-9, and IL-13 [8-10]. Since the role of those cytokines/receptors are well recognized, these molecules have been the main therapeutic targets.

\section{OMALIZUMAB ( Xolair ${ }^{\mathrm{TM}}$, anti IgE)}

The oldest, and therefore deeply studied biological drug in the field of severe asthma is omalizumab. It's a recombinant humanized antibody with a human framework and complementarydetermining region obtained from an anti-IgE murine antibody [11]. It is derived from recombinant DNA which selectively binds to immunoglobulin E (IgE human).

\section{1) PHARMACOKINETIC (PK) CHARACTERISTICS OF OMALIZUMAB}

Omalizumab is marketed in pre-filled syringes with variable dosages and frequency of administration, depending on weight and IgE levels [12]. The absorption of the anti-IgE molecule results to be rather slow, with a peak of absorption within 7-8 days after administration and an average bioavailability of about $62 \%$ [13]. The pharmacokinetics of omalizumab results to be linear at doses above $0.5 \mathrm{mg} / \mathrm{Kg}$. With the subsequent administrations, the area under the serum concentration-time curve (AUC) of omalizumab increases. Once a steady state has been reached the AUC after 14 days results to be greater up to six times compared to the first administration [14]. Specific studies on severe asthmatic people have shown that omalizumab have an apparent volume of distribution of about $78 \pm 32 \mathrm{~mL} / \mathrm{Kg}$ [15]. Although omalizumab form complexes with IgE, it has been observed that these do not exceed the molecular weight of one million Daltons neither in vitro nor in vivo. The clearance of the omalizumab involves IgG clearance processes as well as through specific bonds and formation of complexes with its target ligand, the $\operatorname{IgE}$ [15]. The hepatic elimination of IgG includes degradation in the reticuloendothelial system and endothelial cells. 
Unchanged IgG is also excreted into the biliary fluid. In asthmatic patients it was shown an average elimination half-life of about 26 days, with a clearance of $2.4 \pm 1.1 \mathrm{~mL} / \mathrm{Kg} /$ day $[13,15,16]$.

\section{2) PHARMADYNAMIC (PD) CHARACTERISTICS OF OMALIZUMAB}

The administration of Omalizumab decreases the concentration of free $\operatorname{IgE}$ level, thus preventing the binding of $\mathrm{IgE}$ to high $\left(\mathrm{Fc} \sum \mathrm{RI}\right)$ and low-affinity ( $\left.\mathrm{Fc} \sum \mathrm{RII} / \mathrm{CD} 23\right)$ receptors, interrupting the activation of mast cells and basophils degranulation [11]. Once linked to IgE, Omalizumab, creates small sizes immune complexes, that turn out to be soluble, biologically inert, unable to fix the complement and to precipitate in the kidney [11]. Furthermore Omalizumab, due to the its action reduction of free IgE, promotes a down-regulation of Fc $\sum \mathrm{RI}$ on mast cells and basophils, leading to a reduction in responsivity of these cells to antigens [17]. Several studies demonstrated that basophils histamine release, in people traded with omalizumab, decrease of about $90 \%$ compared with non-treated patients [18]. Clinical studies demonstrated that serum levels of free IgE decreased in a dose-dependent manner within one hour of the first administration and remained stable between doses [19].

\section{MEPOLIZUMAB (Nucala ${ }^{\mathrm{TM}}$, anti IL-5)}

Mepolizumab is a humanized $\mathrm{mAb}$ belonging to the $\mathrm{IgG}_{1 / \mathrm{k}}$ class whose target is IL-5, a cytokine with a crucial role in eosinophils development, maturation and action [20]. This molecule is indicated in subjects with severe uncontrolled asthma and high blood eosinophils levels. The first route of administration in clinical trials was the intravenous one, with different doses $(75 \mathrm{mg}, 250$ $\mathrm{mg}$ and $750 \mathrm{mg}$ ). Subsequently the subcutaneous (SC) administration was chosen at the fix dose of $100 \mathrm{mg}$, regardless of weight or other factors, due to the fact that endpoints obtained with SC and intravenous (IV) administration were overlapping [21]. As the subcutaneous administration has proved to be as effective as the intravenous one, due to a greater simplicity of use and a less 
invasive, the drug has been commercialized in this formulation. Furthermore, in the case of mepolizumab, the subcutaneous formulation also proved to be safer with lower side effects than the $\mathrm{EV}[22]$

\section{1) PHARMACOKINETIC (PK) CHARACTERISTICS OF MEPOLIZUMAB}

The pharmacokinetic of Mepolzumab was assessed in various studies: animal models, humans, healthy and asthmatic patients. We summarize herein the main studies on human model both in healthy asthmatic subjects.

One of the main pharmacokinetic trial, was conducted in an open-label, single-dose, randomized, parallel group 12-week study (study SB-240563/018) [23], where 60 healthy people were enrolled and treated. Different arms of treatment were planned: one received 250 intravenously as a 30 minute infusion $(n=12)$, other groups received the drug subcutaneously in three different body site (abdomen, arm or thigh; $\mathrm{n}=12$ each site) and the last group received an intramuscular injection in the lateral thigh $(\mathrm{n}=12)$. The bioavailability of mepolizumab, through $\mathrm{SC}$ route of administration resulted $64 \%$ in the abdomen, $75 \%$ in the arm and $71 \%$ on thigh, as compared with the one of the intramuscular route that was $81 \%[2,24]$. Maximum plasma concentrations (Cmax) was observed after $0.5-4.8$ hours from the beginning of the infusion. Although the time taken to reach the Cmax was longer (2-14 days) in the SC than the IV administration, mepolizumab was found to be equally well absorbed in both routes of administrations. Consistently with what is known for endogenous IgG1 antibodies in humans [25,26], the half-life of mepolizumab was approximately 20 days, regardless of the route of administration [27].

Several trials are also available, conducted in asthmatic patients. A first study was a multicentre, double-blind, randomized, placebo-controlled, dose escalation study, performed on patients $(\mathrm{n}=38)$ with a mild atopic asthma, where mepolizumab was administrated intravenously one time at the dose of $0.05 \mathrm{mg} / \mathrm{kg}, 0.5 \mathrm{mg} / \mathrm{kg}, 2.5 \mathrm{mg} / \mathrm{kg}$, or $10 \mathrm{mg} / \mathrm{kg}$, than compared with placebo. After the 
administration, the concentration of Mepolizumab decreased with a mean early $t_{1 / 2}$ of about two days. The terminal $t_{1 / 2}$ was documented after about 20 days (14-30 days). The observations done on Cmax and AUC suggested a linear pharmacokinetic profile of the drug [28]. Pouliquen and colleagues described the results of a multi-center, randomized, open-label, parallel-group, repeatdose study where mepolizumab was administered to 70 subjects (66 completed) with asthma and blood eosinophils count of at least 300 cells $/ \mu \mathrm{L}$. Three SC dose of drug $(12.5,125$, and $250 \mathrm{mg})$ were administered subcutaneously and compared to $75 \mathrm{mg}$ intravenously [29]. In this trial the terminal half-life estimated was of 22 days for SC and 28 for IV administration. Regarding $t_{\max }$, the median time was assessed at 6-8 days after SC dosing compared with 0.5 hours in IV dosing. Bioavailability was found to be the same for all SC dosage (74\%). The pharmacokinetic profiles resulted to be more variable at the dose of $12.5 \mathrm{mg}$ than in the other groups. The SC formulation was also evaluated in a trial where $250 \mathrm{mg}$ was administered for three times. Doses 1 and 2 were given 6 weeks apart; dose 3 was given 2 weeks after dose 2. Due to the known half-life of about 20 days, plasma accumulation was observed after third dose. The recorded AUC and Cmax resulted higher after dose 3 than dose $1(65 \%$ and 80\%) [30]. Further data were provided by Ortega et al. where mepolizumab was given subcutaneously at different sites, and compared with intramuscular and IV route. The best SC bioavailability was recorded in arm 75\% (66-86), AUC resulted 1,238 $( \pm 228) \mathrm{mg} \mathrm{d} / \mathrm{mL}$. The half-life was protracted, in a range of 11 to 26 days and independent of dosing route and clearance from 1.9 to $3.3 \mathrm{~mL} /$ day $/ \mathrm{kg}[31]$.

\section{2) PHARMACODYNAMIC (PD) CHARACTERISTICS OF MEPOLIZUMAB}

As it happened for pharmacokinetics studies, also pharmacodynamic one were performed in healthy and asthmatic patients. In the above mentioned trial [23] about 60 people treated with mepolizumab at different dose and different administration routes, the peripheral blood eosinophils count described a substantial decrease of at least $50 \%$ from baseline [23]. In mild-moderate 
asthmatic patients, Leckie and colleagues described the results with an administration of 2.5 and 10 $\mathrm{mg} / \mathrm{Kg}$ intravenously. The blood eosinophil count decreased by $73 \%$ from baseline on $8^{\text {th }}$ day, and by $87 \%$ on day 29 in patients treated with $10 \mathrm{mg} / \mathrm{Kg}$, as compared to $32 \%$ and $34 \%$ in the placebo arm [28]. People treated with $10 \mathrm{mg} / \mathrm{Kg}$ also showed a reduction in blood $(\mathrm{p}<0.001)$ and sputum $(p<0.01)$ eosinophils count post an allergen challenge, compared with placebo. Less apparent results were observed with $2.5 \mathrm{mg} / \mathrm{Kg}$. A subsequent double-blind, randomized, placebo-controlled study, involved the administration of a single IV dose of $0.5 \mathrm{mg} / \mathrm{kg}(\mathrm{n}=4), 2.5 \mathrm{mg} / \mathrm{kg}(\mathrm{n}=4)$ or $10 \mathrm{mg} / \mathrm{kg}$ $(n=4)$, or placebo $(n=6)$. This study confirmed a reduction of blood eosinophils count higher in people treated with mepolizumab (max decrease estimated $85 \%$; IC 50 of $0.45 \mathrm{mg} / \mathrm{mL}$ ) [32]. Pouliquen REF also confirmed the reduction of blood eosinophils with all dosages and routes of administration, although the $12.5 \mathrm{mg}$ dose was less effective. Overall, a significant and prompt reduction in peripheral eosinophils appeared since the third day, with a marginal reduction between 7 and the end of the study day (84 day) [29]. Eosinophils levels decreased not only in blood but also in sputum, starting from day 7 to the end of treatment period (day 84) in all groups, with the largest decreases in the SC 125 and $250 \mathrm{mg}$. Despite the effect of mepolizumab on peripheral eosinophil count is well ascertained, what happens in other organs is not well defined. A reduction has been observed both in bronchial mucosa (biopsies), where a median decrease of 55\% from baseline was recorded at the ninth week of EV administration ( $\mathrm{p}=0.009$ vs placebo), and in bone marrow samples where eosinophils showed a median reduction of $52 \%$, again at the ninth week of treatment $(\mathrm{p}=0.003$ vs placebo). On the other hand, no statistically significant decrease in eosinophils could be demonstrated in bronchoalveolar lavage fluid (BALF) in patients treated with mepolizumab compared with placebo group $(\mathrm{p}=0.4)$, despite the median reduction from baseline was $79 \%$ [33].

5. BENRALIZUMAB (Fasenra ${ }^{\mathrm{TM}}$ anti IL-5Ra) 
Benralizumab is a humanized $\mathrm{mAB}$ of the $\mathrm{IgG}_{1 / \mathrm{k}}$ class which binds $\mathrm{D} 1$ domain of IL-5Ra, or CD125 [34,35] that is expressed on eosinophils and basophils surface [20,36]. This molecule is not fucosylated: this increases its affinity for the Fc $\gamma$ RIIIa receptor, and achieves an antibody-dependent cell-mediated cytotoxicity (ADCC) [20,37]. Similarly to mepolizumab, also benralizumab the eligible patients are severe asthmatic people with high levels of eosinophils ( $>300 \mathrm{cell} / \gamma \mathrm{L})$.

\section{1) PHARMACOKINETIC (PK) CHARACTERISTICS OF BENRALIZUMAB}

The PK characteristics of benralizumab was firstly investigated by Busse and colleagues, in a phase I, multicentre, open-label, sequential dose-escalation study, where the drug was administered in mild atopic asthmatic patients (age 18-45 years). The drug was given according to a dose-incremental design: cohort 1, $0.03 \mathrm{mg} / \mathrm{kg}$; cohort 2, $0.1 \mathrm{mg} / \mathrm{kg}$; cohort 3, $0.3 \mathrm{mg} / \mathrm{kg}$; cohort 4, $1 \mathrm{mg} / \mathrm{kg}$; and cohort 5,3 mg/kg. Two additional cohorts were also added (cohort 6, $0.003 \mathrm{mg} / \mathrm{kg}$; cohort $7,0.0003 \mathrm{mg} / \mathrm{kg}$ ), with the aim to identify the minimum effective dose. The results about mean $\mathrm{C}_{\max }$, at the doses of 0.03 and $3 \mathrm{mg} / \mathrm{kg}$ resulted approximatively dose-proportional $(1 \mathrm{mg} / \mathrm{mL}$ to $82 \mathrm{mg} / \mathrm{mL})$, as well as the $\mathrm{AUC}_{\infty}(5 \mathrm{mg} * \mathrm{~d} / \mathrm{mL}$ to $775 \mathrm{mg} * \mathrm{~d} / \mathrm{mL})$ [38]. As for other mAbs, also benralizumab, in its clearance, behaves like typical human IgG antibodies, with a mean elimination half-life of around 18 day, at the doses of 0.03 and $3 \mathrm{mg} / \mathrm{kg}$. The data held by the researchers also showed a clearance of about $4 \mathrm{~mL} / \mathrm{kg} /$ day, with a faster clearance and a shorter half-life in 0.03 $\mathrm{mg} / \mathrm{Kg}$ group. The large volume of distribution, established between $(52-93 \mathrm{~mL} / \mathrm{Kg})$, suggested a possible drug binding to receptors IL-5Ra expressed by blood cells and/or its penetration into the extravascular tissue [34-38]. Pharmacokinetic effects observed in a Phase II safety study, where benralizumab was administered at three different doses $(25,100$ and $200 \mathrm{mg}$ ) subcutaneously, showed a $\mathrm{C}_{\max }$ between 1.2 and $14 \mu \mathrm{g} / \mathrm{mL}$ and an $\mathrm{AUC}_{\infty}$ between $0.12 \pm 0.071$ and $1.2 \pm 0.11 \mathrm{mg}$ day/mL $[40,41]$.

A pooled analysis took into consideration six different studies to characterize pharmacokinetic and pharmacodynamics characteristics of benralizumab [42]. The resulting pharmacokinetic model was 
a two-compartment model with first-order elimination from the central compartment and with a first-order absorption from the dosing site regarding the SC administration [39]. The calculated mean systemic clearance was $0.321 \mathrm{~L} /$ day, which turned out to be within the therapeutic range of mAbs [43]. The estimated volume of distribution of the central and the peripheral compartments results 3.16 and $2.83 \mathrm{~L}$. In SC administration route the absorption of benralizumab results slow, with a constant rate of 0.252 day with a mean absorption time of 3.97 days. Bioavailability turned out to be $52.6 \%[42]$.

\section{2) PHARMACODYNAMIC (PD) CHARACTERISTICS OF BENRALIZUMAB}

In the trial by Busse et al. benralizumab reduced the blood eosinophil counts, at dosages higher than $0.3 \mathrm{mg} / \mathrm{kg}$ within 24 hours after the administration. The reduction of eosinophil count persisted for at least 12 weeks [38]. In the mentioned phase II safety trial peripheral blood eosinophils count was reduced in all active groups starting from the seventh day, and the reduction was maintained for at least 161 days, this ensuring an acceptable security profile [40,41]. The effect of benralizumab on airways eosinophil population was evaluated in a Phase I study, assessing sputum, bone marrow and peripheral samples. The trial involved mild-to-moderate asthmatic people with sputum eosinophilia higher than $2.5 \%$ despite ICS treatment. The study design involved a single IV administration of $1 \mathrm{mg} / \mathrm{Kg}$ benralizumab or placebo (cohort 1) or three monthly SC doses of benralizumab 100 or $200 \mathrm{mg}$ or placebo every 28 days (cohort 2). Both in the IV or SC administration airway mucosa eosinophil count was reduced, the median decrease from baseline was respectively $61.9 \%$ and $95.8 \%$, and $18.7 \%$ and $89.9 \%$ in sputum sample. Furthermore people treated with benralizumab had a significant suppression of peripheral and bone marrow eosinophils. A similar observation was reported for basophils presenting IL-5Ra [44].

\section{RESLIZUMAB (anti IL-5)}


Reslizumab is an anti-IL-5 mAb, differently by the other anti IL-5 it belongs to the IgG $_{4 / \mathrm{k}}$ class, and it is prescribed in asthmatic patients with eosinophilic disorders [20]. Its formulation is only intravenous and weight-adjusted. Clinical trials where reslizumab was administered subcutaneously did not reach primary endpoint (exacerbations and OCS sparing) so IV administration route is the only available, at the moment (NCT02452190, NCT02501629) [45]. This route and the characteristics of product permit to weight-adjust the dose of drug as detailed below.

\section{1) PHARMACOKINETIC (PK) CHARACTERISTICS OF RESLIZUMAB}

The pharmacokinetic properties of reslizumab were measured in a trial with three groups of patients, healthy $(n=130)$, asthmatic $(n=438)$ and with nasal polyps $(n=236)$, with I.V $3.0 \mathrm{mg} / \mathrm{kg}$ of the drug. After infusion, the peak of drug concentration in serum was assessed, and resulted to decline in a biphasic manner. The calculated volume of distribution, settled in above $5 \mathrm{~L}$, suggests a little extravascular distribution of the drug. AUC was calculated in 27.2 to $33.1 \mathrm{mg} \cdot \mathrm{h} / \mathrm{mL}$. Reslizumab shows a clearance of about $7 \mathrm{~mL} / \mathrm{h}$, resulting in a linear and non-target mediate mechanism. The estimated half-life of reslizumab is 24 days. Usually, liver and kidney are not directly involved in the degradation/excretion of mAbs, thus it is unlikely that liver or kidney failure could modify the PK of the drug, and no dosage adjustment is required [46,48].

\section{2) PHARMACODINAMIC (PD) CHARACTERISTICS OF RESLIZUMAB}

The in vitro studies showed that reslizumab has a great affinity for IL-5 $(\mathrm{Kd}=20 \mathrm{pmol} / \mathrm{l})$ that it efficiently inhibits the binding of IL-5 to Ba/F3 cells (IC50 $=0.5 \mathrm{nmol} / \mathrm{l}$ ), and it is also able to block the proliferation of human erythroleukemic TF-1 cells mediated by IL-5 [49]. The biological inhibition of IL-5 is consequent to the binding of the drug to the small region ERRR (glutamic acid, arginine, arginine, arginine) [50]. In animal model trials on guinea pigs, sensitized with ovalbumin, reslizumab at doses of 0.03 and $0.3 \mathrm{mg} / \mathrm{kg}$ administered intraperitoneally, was shown to suppress the airway hyperactivity, in concomitance with a reduction of pulmonary 
eosinophilia [46]. The administration of $0.3 \mathrm{mg} / \mathrm{kg}$ of reslizumab in severe asthmatic patients with persistent symptoms, induced a reduction in blood eosinophils count ranging between $52.3 \%$ at 48 hours of administration to $18.9 \%$ after 30 days [51]. Increasing the dosage to $1.0 \mathrm{mg} / \mathrm{kg}$ eosinophils reduction the effect was more pronounced and higher up to day 30 . Thus, Reslizumab was able to reduce eosinophil count in blood but also in sputum. A recent study, where reslizumab (3.0 mg/kg), after a 12 months of wash out period, was administered to 10 prednisone-dependent asthmatics, with previous failure of mepolizumab. In this study Reslizumab decreased both sputum by $91.2 \%$ $(\mathrm{P}=0.003)$ and blood eosinophils by $87.4 \%(\mathrm{P}=0.004)$ as compared to placebo. In this trial, out of 10 of patients with persistent high eosinophils level despite mepolizumab, 6 achieved a $<3 \%$ reduction with reslizumab [52].

(Table 1)

\section{DUPILUMAB}

Dupilumab is a fully humanized anti IL-4 receptor $\alpha$ monoclonal antibody, able to blocks both IL-4 and IL-13 [53]. The studied and next to marketing route of administration is the subcutaneous one, with the dose of $300 \mathrm{mg}(150 \mathrm{mg} / \mathrm{ml})$ every two weeks. PK and PD data about this antibody have been studied more in the subject with atopic dermatitis (for which the drug is already on the market) than the one with asthma.

\section{1) PHARMACOKINETIC (PK) CHARACTERISTICS OF DUPILUMAB}

After a single administration of dupilumab (SC), at the dose of 75-600 mg, Tmax recorded was 3-7 days with a bioavailability of $64 \%$. The observed primarily distribution of dupilumab in vascular system allow to calculate a volume of distribution of about $4.6 \mathrm{~L}$. The mean $\pm \mathrm{SD}$ steady-state trough concentrations ranged from $73.3 \pm 40.0 \mathrm{mcg} / \mathrm{mL}$ to $79.9 \pm 41.4 \mathrm{mcg} / \mathrm{mL}$ for $300 \mathrm{mg}$ dose. Dupilumab, at higher concentrations is eliminated principally thought a non- 
saturable proteolytic pathway, instead at low concentrations by a non-linear saturable IL-4R $\alpha$ target-mediated system [54].

\section{2) PHARMACODINAMIC (PD) CHARACTERISTICS OF DUPILUMAB}

In clinical trials, dupilumab has been able to reduce concentrations of type 2 immunity biomarkers, such as thymus and activation-regulated chemokine (TARC/CCL17) [54]. The action of dupilumab allow also to reduce fractional exhaled nitric oxide (FeNO) and circulating concentrations of eotaxin-3, allergen specific IgE, TARC, and periostin in asthma subjects in about 2 weeks, and total IgE concentration but in a longer time, with a median percent reduction from baseline in total $\operatorname{IgE}$ concentrations of $52 \%$ at Week 24 [55] and $70 \%$ at Week 52 [56]. For FeNO, the mean percent reduction from baseline at Week 2 was 35\% [55] and 24\% [56].

\section{CONCLUSIONS}

The development and marketing of biological agents as therapeutic add-on in severe asthma allowed to provide a clinical and therapeutic advancement for patients with uncontrolled asthma. Clinical trials has proved that all these drugs, though through different mechanisms, have been shown to have a good profile of effectiveness and safety [21,57-70]. (Table 2)

In the context of anti IL-5 drugs, and TH2-high asthma, eosinophils maintain a central role in the pathogenesis of the disease. Certainly, the peripheral differential blood count is the most simple and feasible parameter to decide the prescription status of the anti-IL5 drugs. Nonetheless, it should be remembered that eosinophils are mainly marginated in specific organs (i.e. lungs), where they exert their biological action. Therefore it would be correct to evaluate the effect of drugs also at this level, particularly in low/not responder patients. Indeed in the above mentioned manuscript by Mukherjee, despite the low number of patients treated, it seems that a better response could be assessed in whom where the drug reduce more relevantly sputum eosinophils [52]. It is interesting to underline 
that the different action of these drugs (two blocking the cytokine and one its receptor), lead to a common result but in a different way. Acting directly on the cytokine means modulate its action on eosinophils, usually normalizing the number at the peripheral level, as regards the benralizumab, having as its goal the receptor and a pro apoptotic action, we are going to eliminate this population. A direct action on the cell was found to be faster than that on the cytokine, but with the unknown factor of the suppression of a cell population.

The available studies demonstrate that the different pharmacokinetic asset depends on the administration route, therefore the more appropriate administration is of relevance for each drug [71]. Furthermore, in a world where medicine is becoming increasingly personalized, where drugs are modelled on the immunological characteristics of patients, the pharmacokinetic and pharmacodynamic characteristics of biological drugs could play an important role in choosing one drug over another. To choose a drug at the moment we are rightly referring to the mechanism of action, but in the future could be also useful to consider also its pharmacokinetic and pharmacodynamic pattern in order to perform a medicine of precision [72].

In addition, drugs that act on $\mathrm{TH} 2$ phenotype mechanisms will be able soon to respond to those patients when standard of care therapies are not sufficient. Finally, as a perspective, in allergic asthma the use of allergen-specific immunotherapy in combination with biologicals could be also considered, to expand the field of treatments of severe asthma [73].

\section{EXPERT OPINION}

Starting with omalizumab then with mepolizumab currently with benralizumab and reslizumab and soon with dupilumab, additional therapeutic proposals are available for asthmatic allergic and hypereosinophilic patients, where the standard of care is ineffective. The pharmacokinetic and pharmacodynamic studies, so far performed, allowed to better define the mechanisms of action and characteristics of these drugs. However, not all drugs currently marketed have unravelled all doubts. Further observations are needed, particularly in real life, to evaluate the behaviour of such 
molecules in relation, for instance, to the administration of other drugs [74]. A further point to be clarified is the one of the prescribing overlap, both among drugs with the same therapeutic target (anti IL-5 and IL-5r), and in allergic patients but with high blood eosinophils level.

No direct head to head comparison with the mentioned drugs is available, however some data suggest that omalizumab is effective, regardless of eosinophil count [57], and that mepolizumab can control hypereosinophilic patients who had a poor response to omalizumab [75]. Benralizumab probably requires a separate discussion, since the different mechanism of action that involves also basophils CALIMA [63] and SIROCCO [64]. This latter molecule showed an efficacy substantially independent from IgE concentration [76]. No direct data are available in reslizumab trials. Dupilumab demonstrated its efficacy in allergic diseases as atopic dermatitis and also atopic patients. Due to the fact that all these drugs seems to be effective in some cases both in eosinophilic than in allergic patients, specific clinical trials will be needed in this group of patients with common prescription characteristics.

Additionally, administration route could be a factor able to modify PK and PD and consequently, at least hypothetically, able to differentiate action of these drugs. Indeed, a IV administration could offer the advantage of avoiding presystemic degradation, allowing therefore to obtain a greater concentration of drug [46,77]. However, it is true that the route of administration $\mathrm{SC}$ proved to be equally effective and able to reduce the eosinophilic count, improving the symptoms of the patients, in the same way as with EV.

The path of biological drugs for the control of severe asthma is certainly right but needs further investigation to better understand the mechanisms of these drugs. A greater understanding would also be very useful for targeting therapy, making it more and more personalized and precise, sewing it on the patient.

\section{Funding}

This paper was not funded. 


\section{Declaration of interest}

The authors have no relevant affiliations or financial involvement with any organization or entity with a financial interest in or financial conflict with the subject matter or materials discussed in the manuscript. This includes employment, consultancies, honoraria, stock ownership or options, expert testimony, grants or patents received or pending, or royalties.

Acknowledgement: Assistance for this paper was provided by CIPRO (Centro Interprofessionale Pneumologico Ricerca Organizzazione) and ARMIA (Associazione Ricerca Malattie Immunologiche e Allergiche) Genova. 


\section{REFERENCES}

Papers of special note have been highlighted as:

* of interest

** of considerable interest

1. Beasley R. The burden of asthma with specific reference to the United States. J Allergy Clin Immunol. 2002 May;109(5 Suppl):S482-9.

2. GINA gudelines of asthma. http://ginasthma.org/2017-gina-report-global-strategy-forasthma-245 management-and-prevention/. Accessed 02nd Sept 2018

3. Bagnasco D, Ferrando M, Caminati M, et al. Targeting interleukin-5 or interleukin-5R $\alpha$ : safety considerations. Drug Saf (2017) 40(7):559-70.

4. Chung KF, Wenzel SE, Brozek JL, et al. International ERS/ATS 243 guidelines on definition, evaluation and treatment of severe asthma. Eur Respir J. 2014;43: 343-73.

** International definition of severe asthma and criteria to define it as uncontrolled

5. Godard P, Chanez P, Siraudin L, et al. Costs of asthma are correlated with severity: a 1-yr prospective study. Eur Respir J. 2002 Jan;19(1):61-7.

6. Caminati M, Pham DL, Bagnasco D, Canonica GW. Type 2 immunity in asthma. World Allergy Organ J. 2018 Jun 26;11(1):13.

* An interesting review about Th2 mechanisms in asthma

7. Lombardi C, Savi E, Ridolo E, et al. Is allergic sensitization relevant in severe asthma? Which allergens may be culprit? World Allergy Organ J. 2017 Jan 6;10(1):2. 
8. De Ferrari L, Chiappori A, Bagnasco D, et al. Molecular phenotyping and biomarker development: are we on our way towards targeted therapy for severe asthma? Expert Rev Respir Med (2016) 10:9-38.

9. Wynn TA. Type 2 cytokines: mechanisms and therapeutic strategies. Nat Rev Immunol. 2015;15(5):271-282.

10. Oliphant CJ, Barlow JL, McKenzie AN. Insights into the initiation of type 2 immune responses. Immunology. 2011;134(4):378-385

11. Chang TW, Wu PC, Hsu CL, Hung AF. Anti-IgE antibodies for the treatment of $\operatorname{IgE}$ mediated allergic diseases. Adv Immunol. 2007;93:63-119.

12. Luu M, Bardou M, Bonniaud P, Goirand F. Pharmacokinetics, pharmacodynamics and clinical efficacy of omalizumab for the treatment of asthma. Expert Opin Drug Metab Toxicol. 2016 Dec;12(12):1503-1511.

13. Hendeles L, Sorkness CA. Anti-immunoglobulin E therapy with omalizumab for asthma. Ann Pharmacother. 2007 Sep;41(9):1397-410.

14. European Medicines Agency - Xolair - Product information. Available from: http://www.ema.europa.eu/docs/en_GB/document_library/EPAR__Product_Information/human/000606/WC500057298.pdf

15. Food and Drug Administration - Xolair Available from: https://www.accessdata.fda.gov/drugsatfda_docs/label/2003/omalgen062003LB.pdf

16. Bang LM, Plosker GL. Omalizumab: a review of its use in the management of allergic asthma. Treat Respir Med. 2004;3(3):183-99 
17. MacGlashan DW, Bochner BS, Adelman DC, et al. Down-regulation of Fc(epsilon)RI expression on human basophils during in vivo treatment of atopic patients with anti-IgE antibody. $\mathrm{J}$ Immunol Baltim Md 1950. 1997 Feb 1;158(3):1438-45.

18. Noga O, Hanf G, Kunkel G, Kleine-Tebbe J. Basophil histamine release decreases during omalizumab therapy in allergic asthmatics. Int Arch Allergy Immunol. 2008;146(1):66-70.

19. Dodig S, Richter D, Cepelak I, Benko B. Anti-IgE therapy with omalizumab in asthma and allergic rhinitis. Acta Pharm. 2005;55:123-138

20. Varricchi G, Bagnasco D, Borriello F, et al. Interleukin-5 pathway inhibition in the treatment of eosinophilic respiratory disorders: evidence and unmet needs. Curr Opin Allergy Clin Immunol (2016) 16(2):186-200.

21. Ortega HG, Liu MC, Pavord ID, et al. Mepolizumab treatment in patients with severe eosinophilic asthma. N Engl J Med 2014; 371:1198-1207

22. Bagnasco D, Caminati M, Ferrando M, et al. Anti-IL-5 and IL-5Ra: Efficacy and Safety of New Therapeutic Strategies in Severe Uncontrolled Asthma. Biomed Res Int. 2018 Nov $5 ; 2018: 5698212$

23. Schofield JP. An open, randomized, parallel group study to assess the bioavailability following administration at 3 subcutaneous sites and 1 intramuscular site relative to intravenous administration of single $250 \mathrm{mg}$ doses of SB-240563 to healthy volunteers. Brentford: GlaxoSmithKline, 2002 (Data on file)

24. Choi MS, Dixit D, Bridgeman MB. Mepolizumab (Nucala) For Severe Eosinophilic Asthma. P T. 2016 Oct; 41(10): 619-622.

25. Waldmann TA, Strober W. Metabolism of immunoglobulins. Prog Allergy 1969; 13: 1-110 
26. Mould DR, Sweeney KR. The pharmacokinetics and pharmacodynamics of monoclonal antibodies-mechanistic modeling applied to drug development. Curr Opin Drug Discov Devel 2007; 10 (1): $84-96$

27. Smith D, Minthorn EA, Beerahee M. Pharmacokinetics and Pharmacodynamics of Mepolizumab, an Anti-Interleukin-5 Monoclonal Antibody Clin Pharmacokinet 2011; 50 (4): 215 227

28. Leckie MJ, tenBrinke A, Khan J, et al. Effects of an interleukin-5 blocking monoclonal antibody on eosinophils, airway hyper-responsiveness, and the late asthma response. Lancet 2000;356:2144-2148

** One of the first trial using anti IL-5

29. Pouliquen IJ, Kornmann O, Barton SV, et al. Characterization of the relationship between dose and blood eosinophil response following subcutaneous administration of mepolizumab. Int $\mathbf{J}$ Clin Pharmacol Ther. 2015 Dec;53(12):1015-27.

30. Freestone S. A double-blind, placebo controlled, parallel group study to assess the tolerability and pharmacokinetics of three $250 \mathrm{mg}$ subcutaneous doses of SB-240563 in male and female patients with asthma. Brentford: Glaxo- SmithKline, 2001 (Data on file)

31. Ortega H, Yancey S, Cozens S. Pharmacokinetics and absolute bioavailability of mepolizumab following administration at subcutaneous and intramuscular sites. Clin Pharmacol Drug Dev. 2014 Jan;3(1):57-62

32. Freestone S. A double blind, placebo controlled, dose rising study to assess safety and pharmacokinetics of SB-240563 in male patients with mild asthma. Brentford: GlaxoSmithKline, 1998 (Data on file) 
33. Flood-Page PT, Menzies-Gow AN, Kay AB, et al. Eosinophil's role remains uncertain as anti-interleukin-5 only partially depletes numbers in asthmatic airway. Am J Respir Crit Care Med 2003; 167 (2): 199-204

34. Matera MG, Calzetta L, Rinaldi B, Cazzola M. Pharmacokinetic/pharmacodynamic drug evaluation of benralizumab for the treatment of asthma. Expert Opin Drug Metab Toxicol. 2017 Sep;13(9):1007-1013

** exhaustive review about PK and PD of anti IL-5R

35. Ghazi A, Trikha A, Calhoun WJ. Benralizumab - a humanized $m A b$ to IL-5R $\alpha$ with enhanced antibody-dependent cell-mediated cytotoxicity - a novel approach for the treatment of asthma. Expert Opin Biol Ther. 2012;12(1):113-118.

36. Passalacqua G, Matucci A, Vultaggio A, Bagnasco D, Mincarini M, Maggi E, et al. The safety of monoclonal antibodies in asthma. Expert Opin Drug Saf (2016) 15(8):1087-95.

* interesting review about the safety of principal biologic antibodies to treat severe asthma

37. Broughton SE, Nero TL, Dhagat U, et al. The betac receptor family: structural insights and their functional implications. Cytokine 2015; 74:247-258.

38. Busse WW, Katial R, Gossage D, et al. Safety profile, pharmacokinetics, and biologic activity of MEDI-563, an anti-IL-5 receptor antibody, in a phase I study of subjects with mild asthma. J Allergy Clin Immunol. 2010;125(6):1237-1244.

39. Pelaia C, Calabrese C, Vatrella A, et al. Benralizumab: From the Basic Mechanism of Action to the Potential Use in the Biological Therapy of Severe Eosinophilic Asthma. Biomed Res Int. 2018 May 10;2018:4839230 
40. Jin F, White W, Gossage D, et al. Multiple ascending subcutaneous (SC) dose study of MEDI-563: pharmacokinetics and immune response in adult asthmatics [abstract]. European Respiratory Society - 20th Annual Congress, Barcelona, Sept 18-22, 2010, P4553

41. Gossage D, Geba G, Gillen A, et al. A multiple ascending subcutaneous (SC) dose study of MEDI-563, a humanized anti-IL5Ra monoclonal antibody, in adult asthmatics [abstract]. European Respiratory Society - 20th Annual Congress, Barcelona, Sept 18-22, 2010, P1177

42. Wang B, Yan L, Yao Z, et al. Population pharmacokinetics and pharmacodynamics of benralizumab in healthy volunteers and patients with asthma. PT Pharmacometrics Syst Pharmacol. 2017;6(4):249-257.

43. Dirks NL, Meibohm B. Population pharmacokinetics of therapeutic monoclonal antibodies. Clin Pharmacokinet. 2010;49:633-659

44. Laviolette M, Gossage DL, Gauvreau G, et al. Effects of benralizumab on airway eosinophils in asthmatic patients with sputum eosinophilia. J Allergy Clin Immunol. 2013;132:1086-1096.

45. http://ir.tevapharm.com/mobile.view?c=73925\&amp;v=203\&amp;d=1\&amp;id=2327641 .

46. Matera MG, Rogliani P, Calzetta L, Cazzola M. Pharmacokinetic/pharmacodynamic profile of reslizumab in asthma. Expert Opin Drug Metab Toxicol. 2018 Feb;14(2):239-245

47. Deeks ED, Brusselle G. Reslizumab in eosinophilic asthma: a review. Drugs. 2017;77:77784

48. Jaworowicz D, Fiedler-Kelly J, Rabinovich-Guilatt L, et al. The steady-state pharmacokinetic (PK) profile across a range of patient body weight categories supports weightbased dosing for intravenous (iv) reslizumab [abstract]. Am J Respir Crit Care Med. 2016;193:A1389. 
49. Egan RW, Athwal D, Bodmer MW, et al. Effect of SCH55700, a humanized monoclonal antibody to human interleukin-5, on eosinophilic responses and bronchial hyperreactivity. Arzneimittelforschung. 1999;49:779-90

50. Zhang J, Kuvelkar R, Murgolo NJ, et al. Mapping and characterization of the epitope(s) of Sch 55700, a humanized mAb, that inhibits human IL-5. Int Immunol. 1999;11:1935-44.

51. Kipps JC, O’Connor BJ, Langley SJ, et al. Effect of SCH55700, a humanized antihuman interleukin-5 antibody, in severe persistent asthma. Am J Respir Crit Care Med. 2003;167:1655-9.

52. Mukherjee M, Paramo FA, Kjarsgaard M, et al. Weight-adjusted intravenous reslizumab in severe asthma with inadequate response to fixed-dose subcutaneous mepolizumab. Am J Respir Crit Care Med. 2018;197(1):38-46

53. Passalacqua G, Mincarini M, Colombo D, et al. IL-13 and idiopathic pulmonary fibrosis: Possible links and new therapeutic strategies. Pulm Pharmacol Ther. 2017 Aug;45:95-100.

54. https://ec.europa.eu/health/documents/communityregister/2017/20170926138667/anx_138667_en.pdf

55. Wenzel S, Castro M, Corren J, et al. Dupilumab effi cacy and safety in adults with uncontrolled persistent asthma despite use of medium-to-high-dose inhaled corticosteroids plus a long-acting $\beta 2$ agonist: a randomised double-blind placebo-controlled pivotal phase $2 \mathrm{~b}$ doseranging trial. Lancet $2016 ; 388: 31-44$

56. Castro M, Corren J, Pavord ID, et al. Dupilumab Efficacy and Safety in Moderate-toSevere Uncontrolled Asthma. N Engl J Med. 2018 Jun 28;378(26):2486-2496

57. Humbert M, Taillé C, Mala L, et al. Omalizumab effectiveness in patients with severe allergic asthma according to blood eosinophil count: the STELLAIR study. Eur Respir J. 2018 May $10 ; 51(5)$ 
58. Busse W, Corren J, Lanier BQ, et al. Omalizumab, anti-IgE recombinant humanized monoclonal antibody, for the treatment of severe allergic asthma. J Allergy Clin Immunol. 2001 Aug;108(2):184-90

59. Solèr M, Matz J, Townley R, et al. The anti-IgE antibody omalizumab reduces exacerbations and steroid requirement in allergic asthmatics. Eur Respir J. 2001 Aug;18(2):254-61.

60. Pavord ID, Korn S, Howarth P, et al. Mepolizumab for severe eosinophilic asthma (DREAM): a multicentre, double-blind, placebo-controlled trial. Lancet. 2012 Aug $18 ; 380(9842): 651-9$

61. Chupp GL, Bradford ES, Albers FC, et al. Efficacy of mepolizumab add-on therapy on health-related quality of life and markers of asthma control in severe eosinophilic asthma (MUSCA): a randomised, double-blind, placebo-controlled, parallel-group, multicentre, phase $3 \mathrm{~b}$ trial. Lancet Respir Med. 2017 May;5(5):390-400

62. Bel EH, Wenzel SE, Thompson PJ, et al. Oral glucocorticoid-sparing effect of mepolizumab in eosinophilic asthma. N. Engl. J. Med. 2014 371(13), 1189-97.

63. FitzGerald JM, Bleecker ER, Nair P, et al. Benralizumab, an anti-interleukin-5 receptor $\alpha$ monoclonal antibody, as add-on treatment for patients with severe, uncontrolled, eosinophilic asthma (CALIMA): a randomised, double-blind, placebo-controlled phase 3 trial. Lancet. 2016 Oct $29 ; 388(10056): 2128-2141$

64. Bleecker ER, FitzGerald JM, Chanez P, et al. Efficacy and safety of benralizumab for patients with severe asthma uncontrolled with high-dosage inhaled corticosteroids and long-acting ß2-agonists (SIROCCO): a randomised, multicentre, placebo-controlled phase 3 trial. Lancet. 2016 Oct 29;388(10056):2115-2127 
65. Castro M, Zangrilli J, Wechsler ME, Bateman ED, Brusselle GG, Bardin P, et al. Reslizumab for inadequately controlled asthma with elevated blood eosinophil counts: results from two multicentre, parallel, double-blind, randomised, placebo-controlled, phase 3 trials. Lancet Respir Med 2015. 3:355-66

66. Castro M, Mathur S, Hargreave F, Boulet LP, Xie F, Young J, et al. Reslizumab for poorly controlled, eosinophilic asthma: a randomized, placebo-controlled study. Am J Respir Crit Care Med (2011) 184:1125-32.

67. Corren J, Weinstein S, Janka L, et al. Phase 3 Study of Reslizumab in Patients With Poorly Controlled Asthma: Effects Across a Broad Range of Eosinophil Counts. Chest. 2016 Oct;150(4):799-810.

68. Bjermer L, Lemiere C, Maspero J, et al. Reslizumab for Inadequately Controlled Asthma With Elevated Blood Eosinophil Levels: A Randomized Phase 3 Study. Chest. 2016 Oct;150(4):789-798

69. Castro M, Corren J, Pavord ID, et al. Dupilumab Efficacy and Safety in Moderate-to-Severe Uncontrolled Asthma. N Engl J Med. 2018 Jun 28;378(26):2486-2496

70. Rabe KF, Nair P, Brusselle G, et al. Efficacy and Safety of Dupilumab in GlucocorticoidDependent Severe Asthma. N Engl J Med. 2018 Jun 28;378(26):2475-2485

71. Matucci A, Vultaggio A, Danesi R. The use of intravenous versus subcutaneous monoclonal antibodies in the treatment of severe asthma: a review . Respir Res. 2018 Aug $16 ; 19(1): 154$

72. Morse BL, Kim RB. Is personalized medicine a dream or a reality? Crit Rev Clin Lab Sci. 2015 Feb;52(1):1-11 
73. Lombardi C, Canonica GW, Passalacqua G. Allergen immunotherapy as add-on to biologic agents. Curr Opin Allergy Clin Immunol. 2018 Aug 24. doi: 10.1097/ACI.0000000000000479

74. Bagnasco D, Milanese M, Rolla G, et al. Anti-IL-5 therapy in real life. The North-Western Italian experience 3 and comparison with the regulatory trials. WAOJ-D 2018;11:34

75. Galkin D, Liu MC, Chipps BE, et al. Efficacy and Safety of Mepolizumab in Uncontrolled Patients with Severe eosinophilic Asthma Following a Switch from Omalizumab (OSMO Study): Exacerbation and Safety Outcomes. https://doi.org/10.1016/j.jaci.2017.12.965

76. Chipps BE, Newbold P, Hirsch I, et al. Benralizumab efficacy by atopy status and serum immunoglobulin E for patients with severe, uncontrolled asthma. Ann Allergy Asthma Immunol. 2018 May; 120 (5): 504-511.e4

77. Casale TB, Pacou M, Mesana L, et al. Reslizumab Compared with Benralizumab in Patients with Eosinophilic Asthma: A Systematic Literature Review and Network Meta-Analysis. J Allergy Clin Immunol Pract. 2018 Sep 11. pii: S2213-2198(18)30576-2 


\begin{tabular}{|c|c|c|c|c|c|c|c|c|}
\hline Drug & Dose & $\begin{array}{c}\text { Reference } \\
\mathrm{s}\end{array}$ & $\begin{array}{c}\text { Bioavailabilit } \\
y\end{array}$ & $A \cup C$ & Cmax & $\mathrm{CL}$ & Vss & $\mathrm{T} 1 / 2$ \\
\hline Omalizumab & $\begin{array}{c}0.5 \\
\mathrm{mg} / \mathrm{kg} \\
\mathrm{s.c}\end{array}$ & {$[13,14]$} & $62 \%$ & n.a. & n.a. & $\begin{array}{c}2.4 \pm 1.1 \\
\mathrm{~mL} / \mathrm{Kg} / \mathrm{da} \\
\mathrm{y}\end{array}$ & $\begin{array}{c}78 \pm \\
32 \\
\mathrm{~mL} / \mathrm{K} \\
\mathrm{g}\end{array}$ & $\begin{array}{c}26 \\
\text { days }\end{array}$ \\
\hline $\begin{array}{c}\text { Mepolizuma } \\
\text { b }\end{array}$ & $\begin{array}{c}250 \mathrm{mg} \\
\text { s.c }\end{array}$ & [21] & $75 \%$ & $\begin{array}{c}1,238 \pm 228 \mu \mathrm{g} \mathrm{d} / \\
\mathrm{mL}\end{array}$ & $\begin{array}{c}34.1- \\
38.2 \pm 7.3- \\
12.1 \mathrm{mg} / \mathrm{m} \\
\mathrm{L}\end{array}$ & $\begin{array}{c}1.9 \text { to } 3.3 \\
\mathrm{~mL} / \text { day/k } \\
\mathrm{g}\end{array}$ & $\begin{array}{c}55 \text { to } \\
85 \\
\mathrm{~mL} / \mathrm{k} \\
\mathrm{g}\end{array}$ & $\begin{array}{c}11- \\
26 \text { day } \\
s\end{array}$ \\
\hline $\begin{array}{c}\text { Benralizuma } \\
\text { b }\end{array}$ & $\begin{array}{c}0.03-3 \\
\mathrm{mg} / \mathrm{kg} \\
\text { i.v. } \\
25-200 \\
\text { mg s.c. }\end{array}$ & $\begin{array}{l}{[38]} \\
{[40]}\end{array}$ & $\begin{array}{c}\text { n.a. } \\
52.6 \%\end{array}$ & $\begin{array}{c}5 \pm 2-775 \pm 110 \\
\mu \mathrm{g} * \mathrm{~d} / \mathrm{mL} \\
0.12 \pm 0.071-1.2 \pm \\
0.11 \mathrm{mg} \text { day } / \mathrm{mL}\end{array}$ & $\begin{array}{c}1 \pm 0.3-82 \\
\pm \\
18 \mu \mathrm{g} / \mathrm{mL} \\
1.2-14 \\
\mu \mathrm{g} / \mathrm{mL}\end{array}$ & $\begin{array}{c}7 \pm 3-4 \pm \\
0.6 \\
\mathrm{~mL} / \mathrm{kg} / \mathrm{da} \\
\mathrm{y}\end{array}$ & $\begin{array}{c}65 \pm \\
28- \\
71 \pm \\
18 \\
\mathrm{~mL} / \mathrm{k} \\
\mathrm{g}\end{array}$ & $\begin{array}{c}7 \pm 2- \\
16 \pm 3 \\
\text { days }\end{array}$ \\
\hline Reslizumab & $\begin{array}{l}3.0 \mathrm{mg} / \mathrm{k} \\
\text { g i.v. }\end{array}$ & [48] & n.a. & $\begin{array}{c}27.2 \text { to } 33.1 \\
\mathrm{mg} \cdot \mathrm{h} / \mathrm{mL}\end{array}$ & $\begin{array}{l}86.7 \text { to } \\
105.33\end{array}$ & $\approx 7 \mathrm{~mL} / \mathrm{h}$ & $\approx 5 \mathrm{~L}$ & $\begin{array}{l}\approx 24 \\
\text { days }\end{array}$ \\
\hline Dupilumab & $\begin{array}{l}75-600 \\
\text { mg s.c. }\end{array}$ & [54] & $64 \%$ & $\begin{array}{c}73.3 \pm 40.0 \mathrm{mcg} / \mathrm{mL} \\
\text { to } 79.9 \pm 41.4\end{array}$ & n.a. & $\begin{array}{l}0.126 \\
\text { L/day }\end{array}$ & $4.6 \mathrm{~L}$ & $\begin{array}{l}3-7 \\
\text { days }\end{array}$ \\
\hline
\end{tabular}

Legenda: $\mathrm{AUC}=$ area under the serum concentration-time curve, $\mathrm{Cmax}=$ maximum plasma concentrations, $\mathrm{CL}=$ clearance; $\mathrm{Vss}=$ volume of distribution at steady state; $\mathrm{T} 1 / 2=$ elimination half life: $\mathrm{n} \cdot \mathrm{a} .=$ not available

Table 1 


\begin{tabular}{|c|c|c|c|}
\hline Authors & Exacerbations & Other endpoints & Common and serious adverse events \\
\hline \multicolumn{4}{|c|}{ OMALIZUMAB } \\
\hline [57-59] & $\begin{array}{l}\text { ह Exacerbations v.s. } \\
\text { placebo }\end{array}$ & $\begin{array}{c}\text { Lower emergency visit } \\
\text { rate }(0.24 \text { vs } 0.43 \text {, } \\
\mathrm{P}=0.038) \\
\text { ICS dose reduction } \\
\geq 50 \% \text { (median } 75 \% \text { vs } \\
50 \%, \mathrm{p}<0.001) \text { and } \\
\text { discontinuation }(39.6 \% \\
\text { vs } 19.1 \%, \mathrm{p}<0.001), \\
\text { ICS dose reduction } \\
\geq 50 \% \text { (median } 79 \% \mathrm{vs} \\
55 \%, \\
\mathrm{p}<0.001) \text { and } \\
\text { discontinuation }(43 \% \text { vs } \\
19 \%, \mathrm{p}< \\
0.01)\end{array}$ & $\begin{array}{l}\text { Lower respiratory tract infections, } \\
\text { nasopharyngitis, headache, sinusitis, influenza, } \\
\text { cough, upper respiratory tract infection, injection } \\
\text { site reactions } \\
\text { Serious asthma exacerbations requiring } \\
\text { hospitalization, urticarial, depression, } \\
\text { appendicitis, flu-like syndrome, suspected } \\
\text { eosinophilic granuloma of the skull, intestinal } \\
\text { villous adenoma with dysplasia, } \\
\text { infectious mononucleosis, squamous cell } \\
\text { carcinoma of the face }\end{array}$ \\
\hline \multicolumn{4}{|c|}{ MEPOLIZUMAB } \\
\hline$[21,60-62]$ & $\begin{array}{l}\text { \& Exacerbations ( } 53 \% \text { s.c. } \\
\text { MENSA, 32\% SIRIUS, } \\
\text { 48\% DREAM) }\end{array}$ & $\begin{array}{c}\text { 仓ि } \mathrm{FEV}_{1}(98 \mathrm{ml} \text { s.c. } \\
\text { MENSA), no change in } \\
\text { DREAM } \\
\text { ACQ-5 improve } \\
\text { MENSA, SIRIUS, no } \\
\text { variation in DREAM }\end{array}$ & $\begin{array}{l}\text { Nasopharyngitis, upper respiratory tract } \\
\text { infection and headache } \\
\text { Incidence of } 7 \% \text { in intra-venous group, } 8 \% \text { in } \\
\text { subcutaneous, } 14 \% \text { placebo }\end{array}$ \\
\hline \multicolumn{4}{|c|}{ RESLIZUMAB } \\
\hline$[65-68]$ & $\begin{array}{l}\text { ת Exacerbations }(61 \% \text {, } \\
73 \%)\end{array}$ & Improve QoL & $\begin{array}{c}\text { Worsening of asthma symptoms, upper } \\
\text { respiratory tract infections, nasopharyngitis, } 2 \\
\text { anaphylactic reactions, pneumonia, worsening of } \\
\text { asthma }\end{array}$ \\
\hline \multicolumn{4}{|c|}{ BENRALIZUMAB } \\
\hline$[63,64]$ & $\begin{array}{c}\text { תExacerbations }(45 \% \text { in } \\
\text { Q4W, } 51 \% \text { in } \mathrm{Q} 8 \mathrm{~W}),(36 \\
\% \text { in Q4W } \\
28 \% \text { in } \mathrm{Q} 8 \mathrm{~W})\end{array}$ & $\begin{array}{c}\text { 仓िFEV1 (106 ml Q4W, } \\
159 \mathrm{ml} \text { Q8W), (125 ml } \\
\text { Q4W, } 116 \mathrm{ml} \mathrm{Q8W})\end{array}$ & $\begin{array}{l}\text { Nasopharyngitis, worsening of asthma, } \\
\text { headache, dizziness, cough, pyrexia, bronchitis, } \\
\text { anxiety, hyperhidrosis, injection site reaction } \\
\text {,allergic granulomatous angioitis, panic attack, } \\
\text { paraesthesia, injection-site } \\
\text { erythema, urticarial, herpes zoster, chest pain, } \\
\text { pyrexia, tachycardia and anxiety, uterine } \\
\text { leiomyoma, erythema nodosum, thyroid storm }\end{array}$ \\
\hline \multicolumn{4}{|c|}{ DUPILUMAB } \\
\hline$[69,70]$ & $\begin{array}{l}\sqrt{ } \text { asthma exacerbation } \\
(46 \%)\end{array}$ & $\begin{array}{l}\text { 仓िFEV } \mathrm{FE}_{1}(+130 \mathrm{ml}) \\
\text { change of ACQ5 score }\end{array}$ & $\begin{array}{l}\text { conjunctivitis, injection site reactions, and local } \\
\text { herpes simplex infections, Nasopharyngitis, } \\
\text { urinary tract infection, upper respiratory tract }\end{array}$ \\
\hline
\end{tabular}




\begin{tabular}{|c|c|c|c|}
\hline & & infection \\
& & Decrease OCS dose & Hypereosinophilia \\
\hline
\end{tabular}

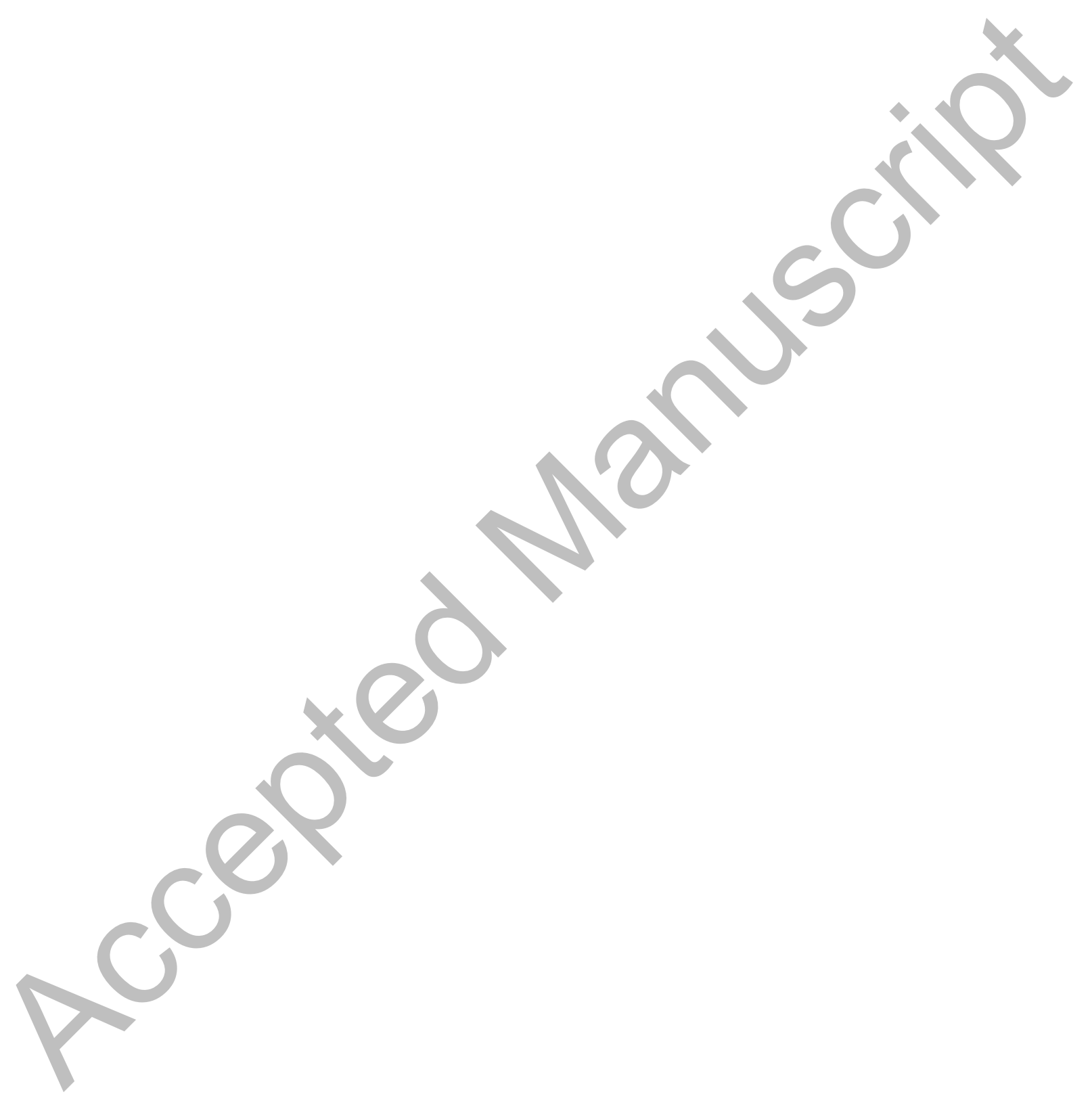

